\title{
PENGIMPLEMENTASIAN TEKNOLOGI PROGRAMMABLE LOGIC DEVICE (PLD) SEBAGAI BINER CODE DECIMAL (BCD) UNTUK SCANNING KEYPAD
}

\author{
Oleh : \\ Muhammad Irmansyah \\ Staf Pengajar Jurusan Teknik Elektro Politeknik Negeri Padang \\ E-mail : kevin_syah@gmail.com
}

\begin{abstract}
Industrial of electronics developed in many fields in the middle of 1990s. Base on this situation, the manufacturer produce the product by increased the function, display, low cost, low power consumption and small size. This kind of product must be supported by complex system, small number of integrated circuit and tiny printed circuit board (PCB). Many integrated technologies such as submicron semiconductor, PCB technology, and the using of PCB surface maximal. The market situation push the producer used modern technology in design and testing for example Programmable Logic Device (PLD). It is the integrated circuit using digital logic which can be changed this function by programming and can be used to industrial application. Programmable Logic Device (PLD) technology can be used to many logical programming by using only one IC. The application of this technology can be found in IC 22 V10 with 24 pins. This IC can be applied to replace the function of IC 74299 as encoder decimal to biner to scanning keypad.
\end{abstract}

Keywords : Programmable Logic Device (PLD), IC PAL 22V10, Biner Code Decimal (BCD), Keypad

\section{PENDAHULUAN}

\section{Latar Belakang}

Pada pertengahan 1990, industri elektronika sangat mengalami perkembangan dalam personal computer, telepon seluler dan peralatan komunikasi data dengan kecepatan tinggi. Untuk persaingan pasar, produsen membuat produk dengan meningkatkan fungsi, penampilan, biaya rendah, konsumsi daya yang rendah dan ukuran yang kecil. Untuk memenuhi kebutuhan ini, produsen menciptakan sistem yang komplek dengan pemakain IC yang lebih sedikit dan ukuran PCB yang lebih kecil. Berbagai teknologi terpadu digunakan seperti proses submikron semikonduktor, teknologi PCB, dan pemaksimalan penggunaan permukaan PCB. Penunjang design digunakan oleh para designer berupa electronic design automation (EDA) tools dan time to market. Kondisi pasar ini membuat metodologi modern dalam design dan tes digunakan, antara lain Programmable Logic Device (PLD) yang merupakan IC digital logic yang bisa dirubah fungsinya melalui pemrograman dan seperti diindustri, akan dapat dilihat bagaimana mudahnya membuat rangkaian digital menggunakan PLD. Programmable Logic Device (PLD) dapat digunakan untuk logika pemrograman yang banyak dengan hanya menggunakan satu IC. Keuntungannya adalah kefleksibelannya 
dalam penggunaan dengan skedul yang lebih ketat, untuk penggunaan pada produk dengan volume yang kecil dan untuk pengaktifan awal sebuah produk meskipun digunakan pada high volume. PLD biasa digunakan pada rancangan yang sederhana dengan jumlah gerbang kurang dari 500 buah.

Piranti encoder yang paling banyak digunakan adalah encoder desimal ke biner. Prinsip kerja dari encoder adalah mengubah system bilangan decimal menjadi bilangan biner. Contohnya, jika saluran bilangan 3 diaktifkan, maka keluarannya akan muncul 0011.

Keypad merupakan susunan saklar push-button menurut baris dan kolom. Keypad 3x4 merupakan modul keypad yang berukuran 3 kolom $\mathrm{x} 4$ baris, yang memiliki 12 tombol dengan tergantung pada aplikasi. Modul ini dapat difungsikan sebagai device input dalam aplikasi-aplikasi seperti pengaman digital, absensi, pengendali kecepatan motor, robotik, dan sebagainya. Keypad digunakan sebagai inputan data berukuran $3 \times 4$ atau 3 kolom 4 baris.

\section{Perumusan Masalah}

1. Bagaimana mengaplikasikan teknologi Programmable Logic Device (PLD) dengan menggunakan IC PAL 22V10 dapat menjadi alternatif dalam merancang dan membuat suatu rangkaian digital.

2. Bagaimana menggunakan IC PAL 22V10 dapat diaplikasikan untuk rangkaian encoder desimal ke biner sebagai pengganti IC 74922 untuk scanning keypad.

\section{Tujuan}

1. Mengaplikasikan teknologi Programmable Logic Device (PLD) dengan menggunakan IC PAL 22V10 dapat menjadi alternatif dalam merancang dan membuat suatu rangkaian digital.
2. Menggunakan IC PAL 22V10 dapat diaplikasikan untuk rangkaian encoder desimal ke biner sebagai pengganti IC 74922 untuk scanning keypad.

\section{TINJAUAN PUSTAKA Programmable Logic Device (PLD)}

Standard Logic Devices (SLD) merupakan IC digital logic yang mempunyai disain tetap. Untuk membuat rangkaian menggunakan IC ini, maka IC diletakkan pada protoboard dan menghubungkanya dengan kabel yang sembrawut seperti spageti (gambar 1).

Untuk mengikuti perkembangan ini, perusahaan elektronika telah mendesain dan membuat produk baru. Untuk memenuhi tuntutan ini, engineers dan teknisi berusaha untuk membuat penemuan yang membantu mereka membuat prototype rangkaian digital dan mengevaluasi kemajuannya dalam waktu yang lama. Salah satunya adalah teknologi Programmable Logic Devices (PLD) yang merupakan IC digital logic yang bisa dirubah fungsinya melalui pemrograman. Pada gambar 2 akan dapat dilihat bagaimana mudahnya membuat rangkaian digital menggunakan PLD.

Untuk lebih menjelaskan keuntungan PLD dapat dibandingkan perbedaan antara membuat rangkaian dengan SLD dan membuat rangkaian yang sama dengan menggunakan PLD.

\section{Membuat Rangkaian Menggunakan SLD}

Sebagai contoh, gambar 1(b) menggambarkan aplikasi dua gerbang NOT, empat gerbang AND dan empat gerbang OR yang terhubung untuk membuktikan fungsi logika seperti table kebenaran pada gambar 1(a). Dua gerbang NOT dan empat gerbang AND membentuk decoder 1 ke 4 .

Decoder ini hanya mempunyai 1 output high berdasarkan nilai biner input 
A dan B seperti tampak pada table kebenaran pada gambar 1(b).

a. Jika $A B=00$, output gerbang AND 0 akan high dan hubungan yang ada pada input gerbang OR 0 dan 1 , maka output Q3, Q2, Q1,Q0 = 0011. Mengacu pada baris kedua tabel kebenaran pada gambar 1(a)

b. Jika $A B=01$, output AND gate 1 adalah high dan hubungan pada input gerbang OR 2 dan 2, maka output Q3, Q2, Q1,Q0 = 1100 .

c. Jika $A B=10$, output gerbang AND 2 akan high, dan memberikan logika high pada input gerbang OR 0 sehingga output menjadi 0001.

d. Jika $A B=11$, output gerbang AND 3 adalah high, dan memberikan logika high pada input gerbang OR 2 sehingga output menjadi 0100 .

Gambar 2.1(c) memperlihatkan bagaimana rangkaian ini dapat dibuat pada protoboard. Begitu selesai, switch harus terhubung ke input dan LCD pada output sehingga rangkaian dapat test untuk melihat logika table kebenaran sudah terpenuhi.

Metoda logika standar dengan prototype mempunyai kerugian:

a. Pemotongan dan penyusunan kabel membutuhkan waktu yang banyak

b. Kesalahan pemasangan kabel sangat tinggi sehingga menyebabkan kerusakan peralatan dan lamanya delay ketika terjadi kesalahan

c. Tingginya Biaya

d. Jika IC yang dibutuhkan tidak tersedia, maka delay yang dihasilkan akan lebih lama

e. Untuk memodifikasi dan menambah rangkaian, kabel dan IC biasanya akan dilepas dari protoboard dan rancangan baru dibuat mulai dari rancangan awal.

Seperti halnya industri, hal ini akan membuat frustasi begitu harus membuat rangkaian lab experiment dengan tangan dan akan lebih baik menggunakan

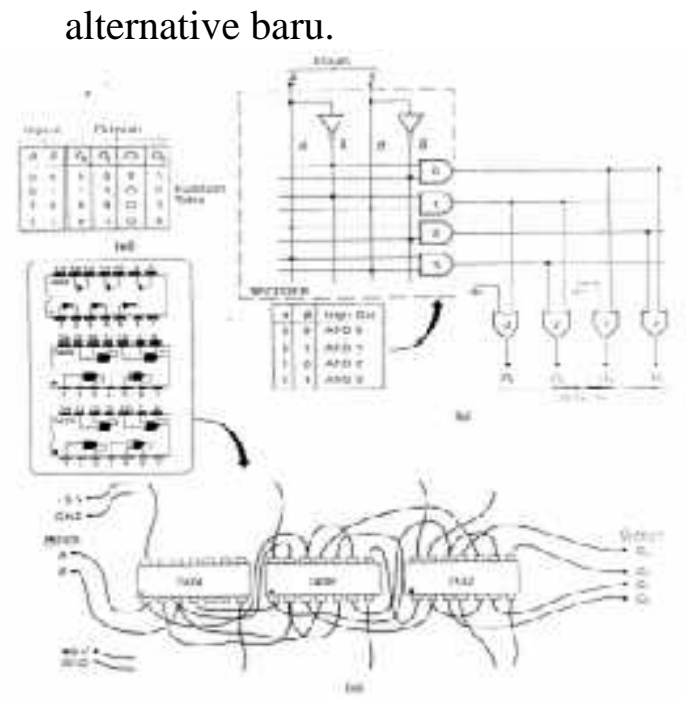

Gambar 1 Konstruksi rangkaian SLD

\section{Membuat rangkaian menggunakan PLD}

Dengan menggunakan PC yang tidak begitu mahal, program software dan IC PLD, prototype rangkaian digital dapat dibuat dengan mudah. Gambar 2(a) dan (b) menunjukkan tabel kebenaran dan rangkaian aplikasi yang sama dari gambar 2.1, tapi untuk tujuan ini PLD digunakan untuk membuat rangkaian seperti yang ada pada gambar 2(c).

Single PLD terdiri dari gerbang logika dalam jumlah yang banyak, termasuk device penghubung dimana semua device ini berada dalam satu IC. Dengan menggunakan PC, logika program dapat dibuat dengan HDL menggunakan text editor atau gambar sederhana dari logika rangkaian dengan menggunakan schematic editor. HDL atau schematic selanjutnya decompile dengan program untuk membuat detail dari rangkaian logika yang akan menghasilkan output dari rancangan yang yang telah dibuat pada HDL atau program. Operasi dari rangkaian ini selanjutnya dapat disimulasikan untuk meyakinkan bahwa output sesuai dengan yang diinginkan. Jika simulasi rangkaian telah sesuai, maka desain selanjutnya 
didownload melalui parallel port ke PLD. Switch dihubungkan ke input dan LCD ke output untuk mencoba test akhir pada prototype.

Langkah-langkah yang dibutuhkan membuat prototype menggunakan PLD: Step 1: Buat rangkaian baru menggunakan schematic editor pada software

Step 2: Compile rangkaian menjadi bitstream file(file.jed), ketika file ini diload ke PLD akan menghasilkan output yang sesuai dengan program diberikan.

Step 3: Buktikan operasi dari rangkaian dengan menggunakan software fungtional dan timing simulator(NOVA)

Step 4: Download file rangkaian daei PC ke PLD

Step 5: Test PLD secara pisik dengan mengaktifkan input dan melihat output yang dihasilkan

Metode pembuatan programmable logic dengan prototype ini mempunyai keuntungan :

a. Dengan pengurangan penggunaan kabel seminim mungkin, prototype dapat dibuat, ditest dan dimodifikasi secepat mungkin

b. Kesalahan dalam penggunaan kabel dapat dihindari

c. Experiment dengan berbagai type IC digital dapat dilakukan tanpa harus menyimpan type IC yang diperlukan

d. Rancangan rangkaian bisa disimpan sebagai file electronic dalam PC dan digunakan lagi begitu diperlukan.

e. Karena PLD dapat digunakan berulang-ulang, modifikasi dapat dilakukan dengan mengubah rangkaian pada PC dengan mudah dan rancangan baru dapat didownload lagi ke PLD

f. Project yang lebih besar dan kompleks bisa dibuat sehingga procedure manual yang membosankan menjadi otomatis.

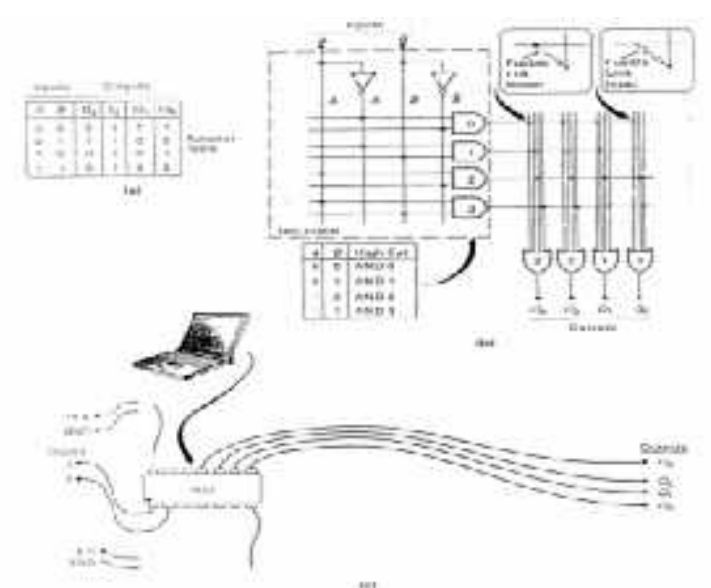

Gambar 2 Konstruksi rangkaian PLD

Salah satu contoh IC yang menggunakan teknologi PLD adalah IC22V10. IC 22V10 terdiri dari 24 Pin.

a. Pin 12 berfungsi sebagai ground

b. Pin 24 berfungsi sebagai catu daya 5 volt.

c. Pin 1 berfungsi sebagai clock atau input

d. Pin 2 sampai 13 (kecuali pin 12) berfungsi sebagai input saja.

e. Pin 14 sampai Pin 23 berfungsi sebagai input atau output.

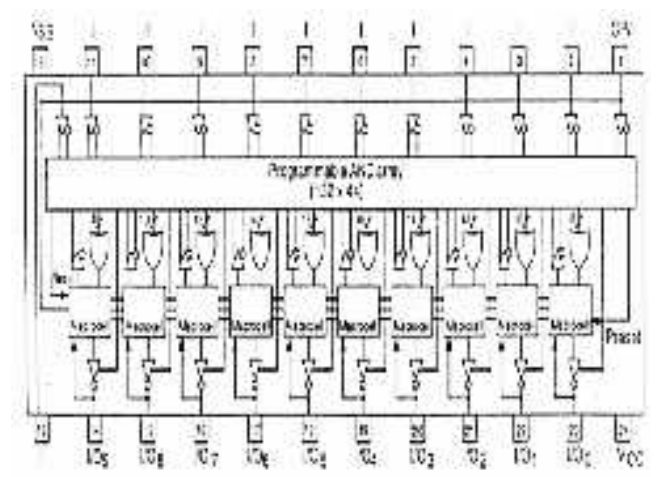

Gambar 3 Konfigurasi IC PAL 22V10

\section{Keypad (3x4)}

Keypad merupakan susunan saklar push-button menurut baris dan kolom. Keypad 3x4 merupakan modul keypad yang berukuran 3 kolom x 4 baris, yang memiliki 12 tombol dengan tergantung pada aplikasi. Modul ini dapat difungsikan sebagai device input dalam 
aplikasi-aplikasi seperti pengaman digital, absensi, pengendali kecepatan motor, robotik, dan sebagainya. Keypad digunakan sebagai inputan data berukuran $3 \times 4$ atau 3 kolom 4 baris. Setiap tombolnya memiliki semacam saklar yang akan short bila ditekan (bernilai ' 0 '). Bentuk dan susunan keypad dapat dilihat pada gambar .

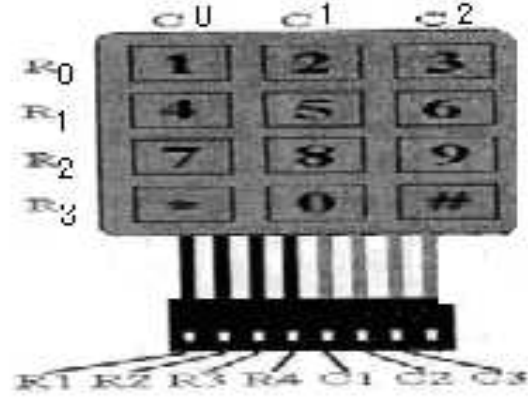

Gambar 4 Keypad 3 x 4

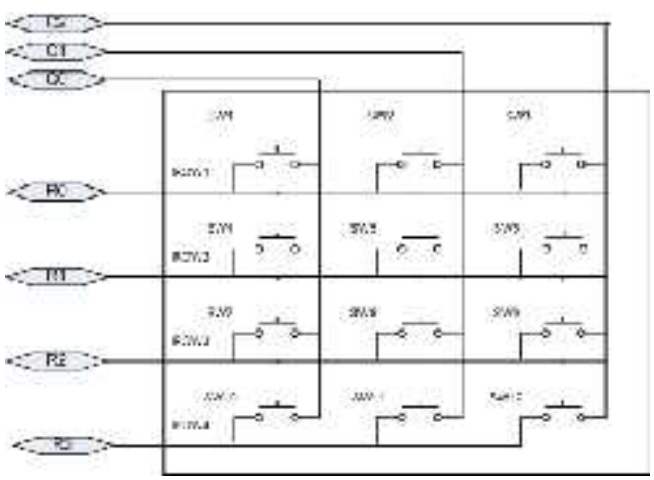

Gambar 5 Rangkaian Scanning keypad

\section{Encoder Desimal ke Biner}

Encoder adalah suatu piranti yang dapat mengubah suatu sistem (contohnya bilangan decimal) yang terdapat pada bagian masukan, menjadi sistem bilangan biner yang terdapat pada bagian keluarannya. Proses pengubahannya disebut Encoding (penyandian atau pengkodean). Pada bagian masukan dari bagian Encoder hanya terdapat satu jalur (tunggal) yang aktif, sedangkan pada bagian keluarannya, yang aktif lebih dari satu, tetapi bagian keluaran ini harus berupa system bilangan biner. Pada hakekatnya, bagian masukan dari encoder adalah sistim bilangan yang biasa digunakan oleh manusia sehari- hari $(0,1,2, \ldots)$. Sedangkan pada bagian keluaran dari encoder biasanya berupa kode dengan sistem bilangan biner yang hanya dimengerti oleh mesin digital atau computer.

Piranti encoder yang paling banyak digunakan adalah encoder desimal ke biner. Prinsip kerja dari encoder adalah mengubah system bilangan decimal menjadi bilangan biner. Contohnya, jika saluran bilangan 3 diaktifkan, maka keluarannya akan muncul 0011.

\section{METODOLOGI PENELITIAN}

\section{Perancangan dan Pembuatan Perangkat Keras Rangkaian Encoder Desimal ke Biner untuk Keypad}

Pada perancangan Programmable Logic Device (PLD) berikut ini adalah membuat IC encoder desimal ke biner sebagai pengganti IC 74922 untuk aplikasi scanning keypad dengan menggunakan satu IC PAL22V10.

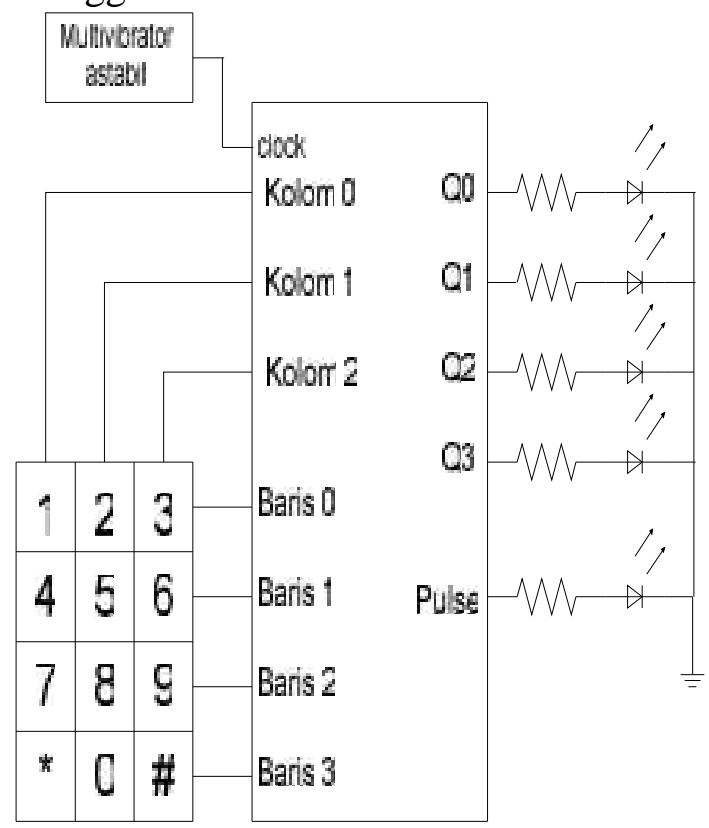

Gambar 6 Rangkaian Encoder Desimal ke Biner untuk Keypad

Dari gambar 6 dapat kita lihat perancangan perangkat keras dari 
encoder desimal ke biner untuk aplikasi keypad yang terdiri dari beberapa bagian yaitu:

1. Multivibrator astabil yang berfungsi sebagai pembangkit pulsa/clock untuk mengubah data.

2. Keypad 3 X 4 yang berfungsi sebagai input desimal.

3. Led yang berfungsi sebagai indikator dari output biner dan pulsa.

4.

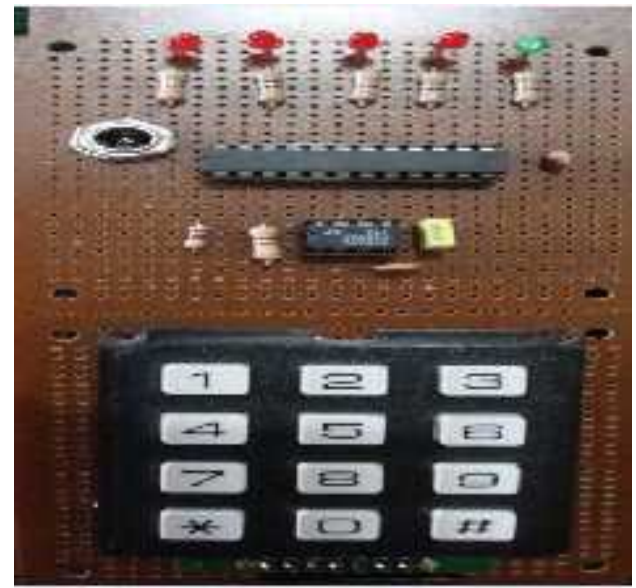

Gambar 9 Perangkat Keras Encoder

Desimal ke Biner untuk Keypad

\section{Perancangan dan Pembuatan Perangkat Lunak}

Perangkat software yang dirancang untuk sistim ini adalah perangkat lunak untuk menjalankan sistim trainer secara keseluruhan, software ini dirancang dengan menggunakan bahasa Warp 4.2.

\section{Software Encoder Desimal ke Biner untuk Keypad}

Library ieee;

Use ieee.std_logic_1164.all;

Entity keypad is port (clk: in std logic;

p: out std;_logoc;

$r$ : in std_logic_vector(3 downto

$0)$;

$q$ : buffer std_logic_vector(1

downto 0);

downto 0); c: buffer std_logic_vector(2

downto 0));

end keypad;

architecture behavioral of keypad is

begin

counter: process (clk)

begin

if (clk'event and clk =' 1 ')

then

$q<=q+1$

end if;

end process counter;

shift: $\operatorname{process}(q)$

begin

case $q$ is

when " $00 "=>c<=$

"110";

when " $01 "=>c<=$

"101";

when " $10 "=>c<=$

"011";

when others $=>c<=$

"111";

end case;

end process shift;

baris_kolom: process $(r, c)$

begin

if $(r=" 1110 "$ and $c=" 110 ")$ then

$d<=$ "0001"; else

if $(r=" 1110 "$ and $c=" 101$ ") then

$d<=" 0010 " ;$ else

if $(r=" 1110 "$ and $c=" 011$ ") then

$d<=" 0011 " ;$ else

if ( $r=" 1101$ " and $c=" 110 ")$

then

$$
\begin{aligned}
& d<=" 0100 " ; \text { else } \\
& \text { if }(r=" 1101 " \text { and } c=" 101 ")
\end{aligned}
$$

then

then

$$
\begin{aligned}
& d<=" 0101 ", \text { else } \\
& \text { if }(r=" 1101 " \text { and } c=" 011 ")
\end{aligned}
$$

$$
d<=" 0110 " ; \text { else }
$$

if $(r=$ "1011" and $c=" 110 ")$ then

$d<=" 0111 " ;$ else

if $(r=$ "1011" and $c=" 101 ")$ then

$d<=" 1000 " ;$ else

if $(r=$ "1011" and $c=$ "011") then 


$$
\begin{aligned}
d<= & =1001 " \text {; else } \\
& \text { if }(r=\text { "0111" and } c=" 110 ")
\end{aligned}
$$

then

$$
\begin{aligned}
& d<=" 1010 " ; \text { else } \\
& \text { if }(r=" 0111 " \text { and } c=" 101 ")
\end{aligned}
$$

then

$$
\begin{aligned}
& d<=" 0000 " \text {; else } \\
& \text { if }(r=" 0111, \text { and } c=" 011 ")
\end{aligned}
$$

then

$$
\begin{aligned}
& d<==1011 " ; \text { else } \\
& d<==0000 " ;
\end{aligned}
$$

end if;

end process baris_kolom;

end behavioral;

\section{Hasil dan Pembahasan}

Hasil Pengujian dan Simulasi Encoder

Desimal ke Biner untuk Keypad

Tabel 1 Hasil pengujian encoder desimal ke biner untuk keypad

\begin{tabular}{|c|c|c|c|c|c|c|c|}
\hline $\begin{array}{c}\text { Tombol } \\
\text { (desimal) }\end{array}$ & Kolom & Baris & D3 & D2 & D1 & D0 & P \\
\hline 0 & 1 & 3 & 0 & 0 & 0 & 0 & pulse \\
\hline 1 & 0 & 0 & 0 & 0 & 0 & 1 & pulse \\
\hline 2 & 1 & 0 & 0 & 0 & 1 & 0 & pulse \\
\hline 3 & 2 & 0 & 0 & 0 & 1 & 1 & pulse \\
\hline 4 & 0 & 1 & 0 & 1 & 0 & 0 & pulse \\
\hline 5 & 1 & 1 & 0 & 1 & 0 & 1 & pulse \\
\hline 6 & 2 & 1 & 0 & 1 & 1 & 0 & pulse \\
\hline 7 & 0 & 2 & 0 & 1 & 1 & 1 & pulse \\
\hline 8 & 1 & 2 & 1 & 0 & 0 & 0 & pulse \\
\hline 9 & 2 & 2 & 1 & 0 & 0 & 1 & pulse \\
\hline$*$ & 0 & 3 & 1 & 0 & 1 & 0 & pulse \\
\hline$\#$ & 2 & 3 & 1 & 0 & 1 & 1 & pulse \\
\hline
\end{tabular}

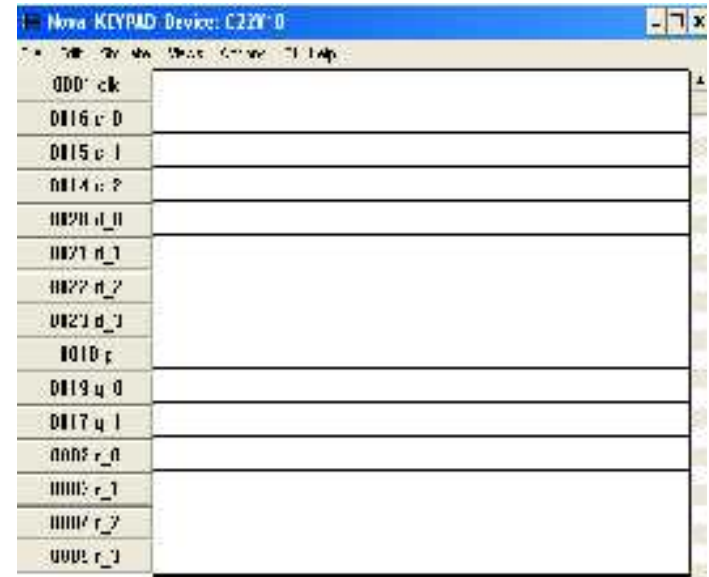

Gambar 10 (a) Tampilan Simulasi Nova

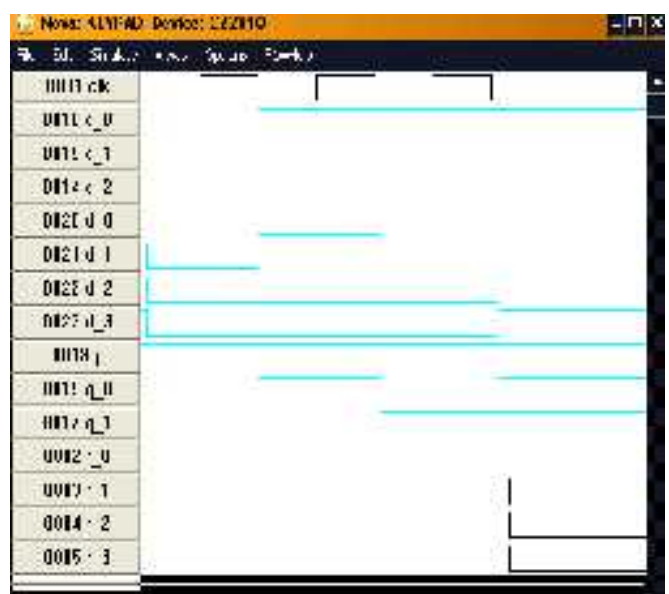

Gambar 10(b) Hasil simulasi encoder desimal ke biner untuk keypad Baris

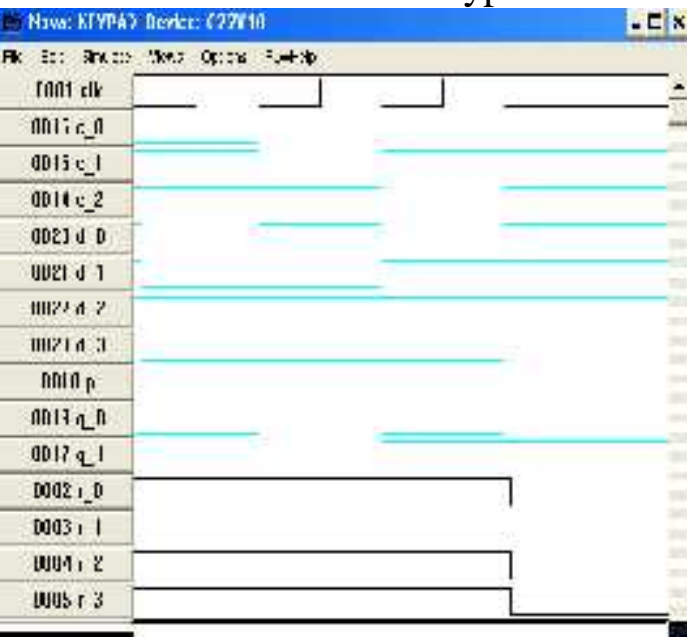

Gambar 10(c) Hasil simulasi encoder desimal ke biner untuk keypad Baris1 


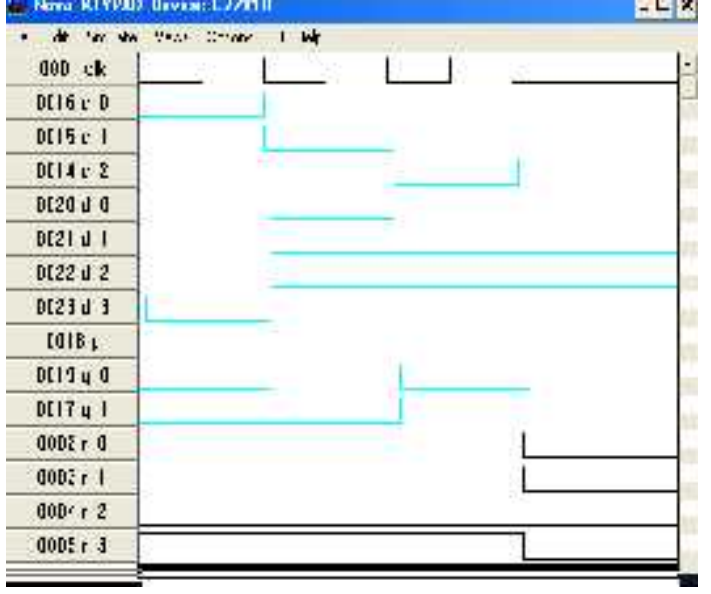

Gambar 10(d) Hasil simulasi encoder desimal ke biner untuk keypad Baris2

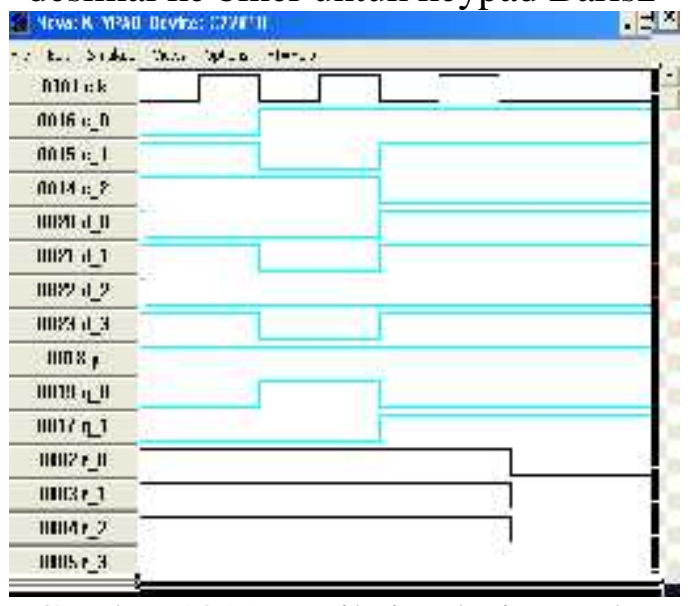

Gambar 10(e) Hasil simulasi encoder desimal ke biner untuk keypad Baris3

\section{Analisa Encoder Desimal ke Biner untuk Keypad}

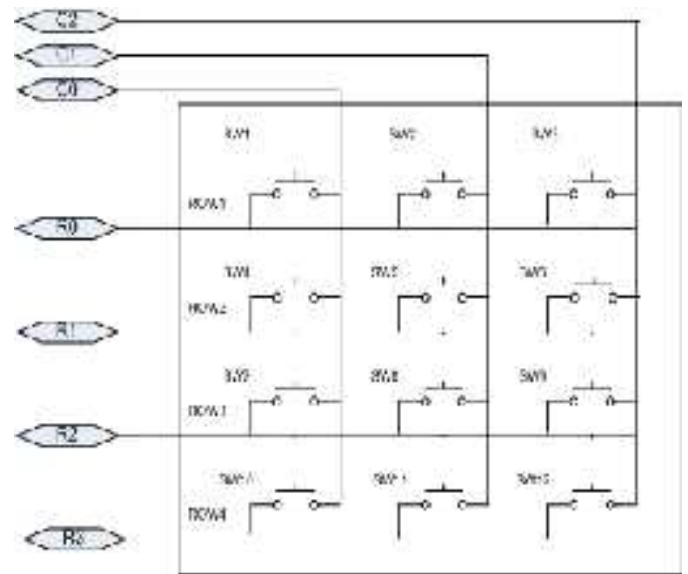

Keypad merupakan perangkat input berupa saklar pushbutton yang terdiri dari susunan baris(R) dan kolom (C). Bentuk dan susunan keypad dapat dilihat pada gambar 4.3. Agar IC PAL22V10 mendeteksi baris dan kolom mana yang terhubung maka beberapa pin difungsikan sebagai output dan beberapa lagi sebagai input. Hubungan pin keypad dengan IC PAL22V10 yaitu R0-R3 yang difungsikan sebagai input, sedangkan C0-C2 difungsikan sebagai output. Untuk mengetahui saklar mana yang ditekan maka akan terjadi proses penscanningan dan pengecekan baris dan kolom. Misalnya, jika saklar angka 1 yang ditekan, maka baris 0 dan kolom 0 akan terhubung singkat (dengan kata lain $\mathrm{R} 0$ dengan $\mathrm{C} 0$ akan terhubung singkat).

Proses penscanningan :

Pada kondisi awal semua output (kolom) berlogika $1(\mathrm{C} 0, \mathrm{C} 1, \mathrm{C} 2)$ berlogika 1 dan semua input (baris) berlogika 1 (R0, R1, R2, R3 berlogika 1). Langkah pertama scanning dilakukan pada output yaitu dengan mengirimkan logika 0 pada kolom 0 (C0) dan pada kolom lainnya berlogika $1 \quad(\mathrm{C} 1=1$ dan $\mathrm{C} 2=1)$. Setelah itu keypad akan membaca input. Jika semua input tetap berlogika 1 berarti tidak ada tombol yang ditekan. Tetapi jika ada tombol yang ditekan maka salah satu data input akan berubah menjadi 0 . Contoh, pada kolom 0 terdapat tombol 1, 4, 7 dan *. Kemudian kita melakukan penekanan pada tombol 4 maka data input akan berubah menjadi $\mathrm{R} 0=1, \mathrm{R} 1=$ $0, \mathrm{R} 2=1, \mathrm{R} 3=1$. Proses seperti ini akan berlanjut untuk proses penscanningan keypad selanjutnya. Untuk lebih jelasnya proses penscanningan keypad dapat kita ihat pada tabel 4.2.

Gambar 11 Scanning keypad 
Tabel 2 Logika input dan output untuk masing-masing penekanan tombol keypad

\begin{tabular}{|c|c|c|c|c|c|c|c|c|c|c|c|}
\hline \multirow{2}{*}{$\begin{array}{c}\text { Tombo } \\
1\end{array}$} & \multicolumn{3}{|c|}{$\begin{array}{c}\text { Kolom } \\
\text { (output) }\end{array}$} & \multicolumn{4}{|c|}{$\begin{array}{c}\text { Baris } \\
\text { (input) }\end{array}$} & \multicolumn{4}{|c|}{$\begin{array}{c}\text { Output } \\
\text { Biner }\end{array}$} \\
\hline & $\mathrm{C} 0$ & $\mathrm{C} 1$ & $\mathrm{C} 2$ & $\mathrm{R} 0$ & R1 & R2 & R3 & D3 & $\mathrm{D} 2$ & D1 & D0 \\
\hline 1 & 0 & 1 & 1 & 0 & 1 & 1 & 1 & 0 & 0 & 0 & 1 \\
\hline 2 & 1 & 0 & 1 & 0 & 1 & 1 & 1 & 0 & 0 & 1 & 0 \\
\hline 3 & 1 & 1 & 0 & 0 & 1 & 1 & 1 & 0 & 0 & 1 & 1 \\
\hline 4 & 0 & 1 & 1 & 1 & 0 & 1 & 1 & 0 & 1 & 0 & 0 \\
\hline 5 & 1 & 0 & 1 & 1 & 0 & 1 & 1 & 0 & 1 & 0 & 1 \\
\hline 6 & 1 & 1 & 0 & 1 & 0 & 1 & 1 & 0 & 1 & 1 & 0 \\
\hline 7 & 0 & 1 & 1 & 1 & 1 & 0 & 1 & 0 & 1 & 1 & 1 \\
\hline 8 & 1 & 0 & 1 & 1 & 1 & 0 & 1 & 1 & 0 & 0 & 0 \\
\hline 9 & 1 & 1 & 0 & 1 & 1 & 0 & 1 & 1 & 0 & 0 & 1 \\
\hline$*$ & 0 & 1 & 1 & 1 & 1 & 1 & 0 & 1 & 0 & 1 & 0 \\
\hline 0 & 1 & 0 & 1 & 1 & 1 & 1 & 0 & 0 & 0 & 0 & 0 \\
\hline$\#$ & 1 & 1 & 0 & 1 & 1 & 1 & 0 & 1 & 0 & 1 & 1 \\
\hline
\end{tabular}

\section{Kesimpulan}

1. Teknologi Programmable Logic Device (PLD) dengan menggunakan IC PAL 22V10 dapat menjadi alternatif dalam merancang dan membuat suatu rangkaian digital.

2. IC PAL 22V10 dapat diaplikasikan untuk rangkaian encoder desimal ke biner sebagai pengganti IC 74922 .

3. IC PAL 22V10 dapat diaplikasikan untuk rangkaian encoder desimal ke biner untuk scanning keypad.

\section{DAFTAR PUSTAKA}

Irmansyah,M, 2008

Programmable Logic Device (PLD) Trainer, Penelitian DIPA Politeknik Negeri Padang

Irmansyah,M，2010 Rancang Bangun Sistim Digital Sebagai Kunci Password Dengan Mengintegrasikan Teknologi Programmable Logic Device (PLD) dan Teknologi Mikrokontroller MCS-51, Penelitian DIPA Politeknik Negeri Padang Irmansyah,M,2009,"Gerbang

Logika Berbasis Programable Logic Device (PLD)",Jurnal, Politeknik Negeri Padang

Irmansyah,M,2009,'Multiplexer Berbasis Programable Logic Device (PLD), Jurnal, Politeknik Negeri Padang

Irmansyah,M,2010,'Dekoder

Biner ke Desimal Berbasis Programable Logic Device (PLD), Jurnal, Politeknik Negeri Padang

Kevin Skahill, 1997, "VHDL for Programable,Addison Wesley

Neil H.E Weste,2005,"CMOS VLSI Design", Addison Wesley

Nigel P,Cook,2004,'Practical

Digital Electronics",Prentice Hall

Setiawan,Rahmat,2009,'Panduan Paktikum PLD",Surabaya

Stephen Brown,2000,Digital Logic

Of Fundamentals With VHDL Design",Mcgraw-Hill 
ISSN :2085-6989

\section{HALAMAN INI SENGAJA DIKOSONGKAN}

